\title{
TRATAMENTO DE FRATURA DO TERÇO MÉDIO DA FACE - RELATO DE CASO
}

Felipe Bueno Rosetti BERNABÉ, Paulo Roberto MÜLLER, Delson João DA COSTA, Nelson Luis Barbosa REBELLATO, Leandro Eduardo KLÜPPEL

As fraturas do terço médio da face são geralmente causadas por acidentes automobilísticos e incluem aquelas que afetam a maxila, o zigoma e o complexo naso-orbito-etmoidal. Nas fraturas faciais, os objetivos do tratamento incluem a rápida cicatrização óssea; o retorno das funções oculares, mastigatória e nasal normais; a recuperação da fala e um resultado estético facial e dental aceitável. Para alcançar esses objetivos, deve-se reposicionar os fragmentos ósseos de forma anatômica e promover algum tipo de fixação interna estável. Um paciente de 39 anos, sexo masculino, foi encaminhado ao pronto-socorro do Hospital XV após ter sofrido acidente automobilístico. Durante o exame clínico, apresentou afundamento em região zigomática e hemorragia subconjuntival do lado esquerdo, hematoma em terço médio de face, dor e sensibilidade à palpação, laceração em lábio superior, alteração oclusal e fonética. Ao exame de imagens constatou-se a presença de fratura do complexo zigomático esquerdo, maxila (Le Fort I) e região nasal. $O$ tramento foi realizado sob anestesia geral, foi feita redução anatômica dos segmentos fraturados e fixação interna rígida com placas e parafusos. Decorridos 6 meses da intervenção, o paciente encontra-se sem alterações estéticas ou funcionais.

Palavras-chave: Trauma; Fratura; Cirurgia; Face; Fixação de fratura. 